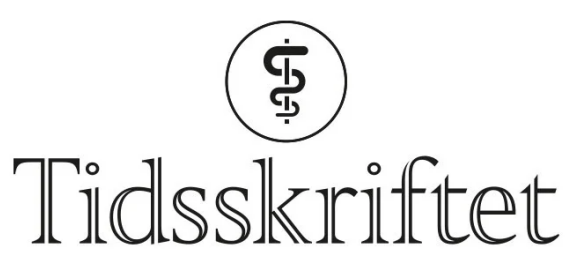

DEN NORSKE LEGEFORENING

\title{
Omsorg ved livets slutt
}

\author{
ANMELDELSER
}

BJØRGULF CLAUSSEN

Institutt for helse og samfunn

Universitetet i Oslo

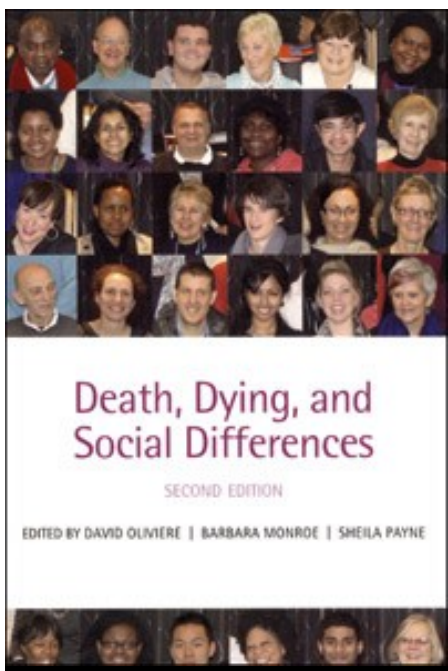

Oliviere, David

Munroe, Barbara

Payne, Sheilla

Death, dying, and social differences

2. utg. 226 s, ill. Oxford: Oxford University Press, 2011. Pris GBP 35

ISBN 978-0-19-959929-5

Omsorgen for døende utenom de etablerte hospicene er temaet for denne boken. Budskapet er viktig: Mange andre sosiale grupper burde få en liknende omsorg som pasienter på hospice får ved livets slutt. Den er skrevet av folk som er knyttet til hospicene, og de har mye å fare med.

I den første delen forklarer forfatterne formålet generelt og grundig. De fremhever at hospicepasientene stort sett har langtkommen kreft, der forløpet er forholdsvis kjent og kortvarig. Denne delen blir altfor ordrik. 
Den andre delen er derimot langt fra selvfølgelig. Her kommer en mengde vurderinger og noen erfaringer med slikt arbeid blant en rekke sosiale grupper. Disse pasientene er mye «vanskeligere» enn de typiske hospicepasientene, de har gjerne et mer langtrukkent siste stadium med ulike symptomer. Dette gjelder den langt største gruppen, nemlig de vanlige sykehjemspasientene. De er tatt hånd om av institusjoner, dessverre med få faglige og menneskelige ressurser sammenliknet med hospicene. I England er hospicene nå private. Spørsmålet er om personalet på sykehjemmene kan lære noe av hospicene, selv med små ressurser.

Motsatt står de alvorlig syke narkomane som har vekslende og uberegnelige forløp og dertil ofte har svært individuelle behov, både medisinsk og sosialt. De dør ofte under forhold som opprører alle, men av og til på sykehus. Ingen forsøk med hospice for disse er kjent, bare enkeltkasus, men forfatterne gir noen gode råd.

Andre viktige grupper er psykisk syke, psykisk utviklingshemmede, demente, fanger, flyktninger, hjemløse og romfolket - ulike grupper som alle får egne kapitler. Ungdom kan også ha særegne behov, noe forfatterne diskuterer. De har sikkert rett i at mange i disse gruppene burde tilbys en bedre omsorg ved livets slutt enn de stort sett får i dag.

Romfolket har interessante særtrekk i sin kultur i forhold til døden. De dør på sykehus fordi de ikke kan besmitte hjemmet ved å dø der. De vekker gjerne oppsikt på sykehuset fordi alle slektninger og venner skal ta avskjed, gjerne 150 mennesker og ofte med omfattende ritualer. Noen sykehus i England har egne rom for dette.

Alle som jobber med omsorg for disse gruppene, har noe å lære av denne boken. Jeg anbefaler den derfor for alle som er interessert i omsorg ved livets slutt. Ledelsen ved alle sykehjem bør antakelig diskutere temaet, om de da ikke nylig har gjort det.

Publisert: 21. februar 2012. Tidsskr Nor Legeforen. DOI: 10.4045/tidsskr.11.143o

(C) Tidsskrift for Den norske legeforening 2023. Lastet ned fra tidsskriftet.no 26. april 2023. 